\title{
Evaluations of Drug-Drug Interactions in Hypertensive Patients in Secondary Care Hospital
}

\author{
Sagar Pamu ${ }^{1 *}$, Tribhuvan Singh ${ }^{1}$, S. Ravi ${ }^{3}$, S.V. Ranganayakulu ${ }^{2}$. \\ ${ }^{1}$ Guru Nanak Institutions Technical Campus-School of Pharmacy, Ibrahimpatnam, Hyderabad-501506. \\ ${ }^{2}$ Guru Nanak Institutions Technical Campus-School of Engineering and Technology, Ibrahimpatnam, \\ Hyderabad-501506. \\ ${ }^{3}$ Rural Development of Society, R\&D Centre, Punjagutta, Hyderabad-500082.
}

\begin{abstract}
Objectives

1. Retrospective survey of potential Drug-Drug interactions.

2. To analyse the risk which it was associated with drug interaction in hypertensive patients.

3. To identify the drug that most commonly implanted in Drug-Drug interactions and to recognise the antihypertensive drug mostly interacting with other drug.

Methodology

The study was done at general medicine ward of secondary care hospital in Secunderabad for a period of 9 months for the detection of drug interactions in prescriptions containing anti hypertensive drugs which was prescribed. The study involves following steps

* Collection of prescription (schedule method).

* Recording of prescription details.

* Analyzing prescriptions and finding the individual drug interaction.

Findings

A total of 151 prescriptions were collected on the basis of inclusion (age, sex, other diseases like DM, etc) and exclusion (pregnant) criteria and analyzed for drug-drug interactions. It is shown that 20\% (31) of prescriptions having drug-drug interactions in hypertensive patients. From these amlodipine is interacting with 8 drugs, furosemide with 5 drugs, atenolol with 6 drugs, enalapril with 5 drugs, ramipril with 3, digoxin with 2, nifedipine with 2, nebivolol with 2. From this study we concluded that amlodipine and digoxin, were commonly interacting with more no of drugs and nifedipine and nebivolol are least. Those 31 drug interactions case sheets were individually again studied and found that there were 26 different drug combinations causing interactions. Some drugs were interacting with more than one drug in the list. The severity of these 26 different interactions was founded that there were 4 major interaction and 15 moderate interactions. From this individualized study, amlodipine was found to be most interacting drug and combination which repeated mostly was amlodipine and atenolol, causing reduction in heart rate, cardiac contractility and hypotension.
\end{abstract}

Conclusion

It is concluded that the drug interaction cases constitutes $20 \%$ among the 151 hypertensive prescriptions. In future these drug interactions effectively overcome by

- Dose adjustment.

- Monitor blood pressure.

- Use combination with caution.

- $\quad$ Clinically monitoring the patient.

Keywords: Hypertension, Drug interactions, Prescriptions, Retrospective survey, Amlodipine

\section{Introduction}

The cardiovascular morbidity and mortality is directly correlated with blood pressure (BP) and its risk is also correlated with the drug interactions where the antihypertensive drugs interact with other drug in the rescription of hypertensive patients. Drug Interactions are an important cause of drug related problems and the ability to recognise and manage drug interactions is a crucial role of the pharmacist in optimising patient outcomes in hypertensive patients. An important skill is to be able to recognise clinically significant drug interactions and provide management advice to the patient and their doctor. This advice may include discussing dose alteration strategies or alternative non-interacting drug combinations.

Drug-drug interactions cause hospitalizations attributed to drugs in the elderly. In most cases they are erroneously interpreted as patient deterioration because of illness, poor adherence to in treatment, or infection. In the United States $25 \%$ of ambulatory patients taking drug combinations were at risk for clinically important interactions ${ }^{1}$. 
A drug-drug interaction is defined as a pharmacokinetic or pharmacodynamic influence of drugs on each other, which may result in desired effects, in reduced efficacy and effectiveness or in increased toxicity. A drug interaction is a situation in which a substance affects the activity of a drug, i.e. the effects are increased or decreased, or they produce a new effect that neither produces on its own. Variability in pharmacokinetics (what the body does to the drug) and pharmacodynamics (what the drug does to the body) means that even clinically significant interactions are often unpredictable in the magnitude of their effect ${ }^{2}$.

There are several mechanisms by which drugs interact with other drugs, food, and other substances. An interaction can result when there is an increase or decrease in: the absorption of a drug into the body; distribution of the drug within the body; alterations made to the drug by the body (metabolism); and elimination of the drug from the body ${ }^{3}$.

Drug interactions also may occur when two drugs that have similar (additive) effects or opposite (cancelling) effects on the body are administered together. For example, there may be major sedation when two drugs that has sedation as side effects are given, such as, narcotics and antihistamines. Another source of drug interactions occurs when one drug alters the concentration of a substance that is normally present in the body. For example Warfarin acts by reducing the concentration of the active form of vitamin $\mathrm{K}$ in the body. Therefore, when vitamin $\mathrm{K}$ is taken, it reduces the effect of warfarin.

The reasons for increased drug interactions are like drug abuse and misuse; patients consult several physicians, concurrent use of prescription and non-prescription drugs, patient non-compliance, drug potency. Drug-drug interactions can lead to severe side effects and have resulted in early termination of development of drugs, refusal of approval, severe prescribing restrictions and withdrawal of drugs from the market. Whether a given magnitude of effect of an interacting inhibitory drug (i.e., Precipitant drug) on plasma levels of a recipient drug (i.e., Object drug) which results in an increased risk of adverse events depends to a great extent on the therapeutic index of the recipient drug. Even small pharmacokinetic interactions can result in significant pharmacodynamic adverse effects for drugs of a narrow therapeutic index. Many physicians and other health care providers have only a rudimentary knowledge regarding drug-drug interactions.

With the seemingly constant flow of new therapeutic agents and new treatment indications for existing medications, polypharmacy is increasingly common. Many drug interactions are avoidable, but those that are not require awareness of the interaction to allow for proper management and appropriate dosage adjustments. The issue of drug interactions is bound to come up. It is therefore prudent to learn about such interactions so they can be effectively managed. Intelligent choices with respect to medication combinations can be made, and doses can be adjusted to keep patients in safe therapeutic zones.

Drug interactions a condition may occur when an existing medical condition makes certain drug potentially harmful (e.g., Tobramycin in combination with frusemide in renal failure patient's worse the condition by increasing the nephrotoxicity).

There are multiple factors that can influence the outcome of a drug interaction. These factors are based on the properties of the object drug and the precipitating drug 4 .

\section{Object Drugs}

- Those which have low therapeutic index (e.g., Digoxin)

- Those which have a steep dose-response curve (e.g., aminoglycoside antibiotics.)

Precipitant Drugs

- $\quad$ Those which are highly protein bound (e.g., Aspirin), and therefore likely to displace object drugs from protein binding sites.

- Those which stimulate (e.g., rifampicin) or inhibit (e.g., cimetidine) the metabolism of other drugs.

- Those which affect renal function (e.g., Probenecid) and alter the renal clearance of object drug.

There are about more than 6000 drugs available worldwide, along with traditional medicines and herbal remedies that can potentially interact. It is important to use pharmacological knowledge together with the medical literature to evaluate a potential drug interaction. Information is available from a wide range of sources such as in vitro and animal studies, case reports(journals and pharmacovigilance reports), clinical trials, review papers, handbooks (stockleys drug interaction), and monographs in books, Tables, Charts and Data sheets (British National Formulary), databases software (micromedex) on the World Wide Web. It is important that pharmacist is familiar with and use this information appropriately.

\section{Method}

Hypertension is one of the major disease which is found in a large numbers of patients with other associated diseases. Globally $40 \%$ populations were affected by cardiac disorders, from them $1 / 4$ people affected by hypertension. Due to this there will be increase number of drugs prescribed in the prescription and thereby increasing the chances for drug- interactions. Hence our present study is an attempt to analyse the prescriptions and to find out presence and absence of drug interactions. 
Before the start of this study the literature surveys were done for the understanding of conditions in hypertensive patients. Later the study is done to analyse the prescriptions where the physician prescribed the medications in hypertensive patient's prescription in secondary care hospital in Salem, and to find out drug drug interactions in hypertensive patients.

In this study first the area i.e Secunderabad was selected and over there a secondary care hospital was selected where the treatment to patient is at free of cost i.e, the hospital is a trust. The study was decided to do upto 9 months of period which includes the season's winter and summer. The study was done in retrospective method $^{4}$ where the cases were collected from medical record room of general medicine department in the hospital. The data was collected in schedule method ${ }^{5}$ where the study involves the detection of presence and absence of drug interactions in the prescriptions containing antihypertensive drugs. The inclusion and exclusion criteria of prescriptions were analysed.

In this study a total of 151 of hypertensive cases were collected in the process of schedule method and recorded the details of prescription in proforma-1 and proforma-2. The months and number of prescription collected and its percentage were shown in table-1. The patient details of each case sheet and the prescription details were noted in the Proforma 1(it includes Name, Age, Sex, Department, Ip.no, Date of admission, Date of discharge, Diagnosis, and Drug chart) and Proforma 2(it includes the details of drug-drug interactions, severity and its remedy)

The collected prescriptions were analyzed for the drug interactions with antihypertensive agents. It was analyzed by selecting each prescription and the drugs in each of them have been evaluated for the drug interactions. The founded drug interactions were categorised as according to the severity. If a medication contains two or more pharmacologically active drugs, then each drug was counted individually in the analysis (e.g.amlodipine with atenolol).

The collected data were cross referenced to each other for evaluating the drug-drug interactions with antihypertensive agents. The results of proforma-2 details were shown in table-2. The report is prepared for its remedy for better patient complaints and finding the most interacting drug with antihypertensive agents.

\section{Results And Discussion}

Antihypertensive treatment has proven benefits, and the number of patients being treated with these drugs is significant. Hypertensive patients may have other medical illnesses for which they receive medications, and interactions between antihypertensive agents and other drugs are likely. Some of these interactions may lead to undesirable effects or even loss of blood pressure control. However, drug interactions can also be beneficial when 2 antihypertensive drugs with different pharmacological actions are prescribed in combination and with a clear therapeutic objective in mind. Clinicians should be aware of the mechanisms and the consequences of the different types of interaction in hypertensive patients, so that a desired pharmacological response can be achieved with the fewest side effects in the patients.

The drug interactions can be classified but with the relevance of a particular drug interaction is difficult to determine to a specific patient using this tool. The classification of drug interaction is followed as Major Highly significant in clinical aspects. Avoid the combinations where the risk of interaction outweighs the benefit. Moderate - Moderately significant in clinical aspects. Usually the combinations should avoid but use it only under special circumstances.

Minor - Minimally significant in clinical aspects. Assess the risk, minimize it and consider an alternative drug, take the steps to circumvent the the interaction risk and/or plan for monitoring sessions. Based on the literature review and from the data, it shows the seriousness of drug- drug interactions, the present work was attempted to detect presence and absence, types of drug interactions and number of drug interactions happened in general medicine, in Secondary care hospital, Salem.

In this study a total of 151 hypertensive inpatient casess were collected in the duration of 9 months (September 2015 to May 2016) from Secondary care hospital, Secunderabad, and categorized based on numbers of hypertensive case in month. The results of cases collected in each month were shown in the following table- 1 . From the total of 151 hypertensive cases, 31 cases found to have drug interactions with anti hypertensive agents and 120 cases were not founded with interactions.

The 31 drug interaction prescription were analysed and founded the 26 different types of drugs interacting with antihypertensive agents and its effects with management were depicted in the table-2. The severity of these 26 different interactions was founded that there were 4 major interaction and 15 moderate interactions.

These antihypertensive agents are having the interactions with different classifications of agents like antifungal drugs, anticoagulant drugs, analgesics, antihypertensive drugs, anxiolytics, antigout drugs, antibacterial drugs, diuretics, and lipid lowering drugs and the entire individual each class of drugs and percentage of each drug interactions were depicted in the table-3. 


\section{Summary And Conclusion}

A retrospective study was done to analyze the hypertension cases in the medical ward of a secondary care hospital, Secunderabad for evaluating drug-drug interactions for a period of nine months from September 2015 to May 2016.

From the total 151 inpatient hypertensive prescriptions, 31 prescriptions were found to occur drug interactions with antihypertensive agents. From these amlodipine is interacting with 8 drugs, furosemide is with 5 drugs, atenolol with 6 drugs, enalapril with 5 drugs, ramipril with 3, digoxin with 2 , nifedipine with 2 , nebivolol with 2 . From this we concluded that in the hospital large number of drugs is interacting with amlodipine, and digoxin, nifedipine and nebivolol is very less.

Those 31 drug interactions case sheets were individually again studied and found there were 26 different drug combinations causing interactions. These combinations were made by 26 individual drugs with 4 major and 15 moderate interactions. Some drugs were interacting with more than one drug in the list. Some drugs are repeatedly interacted from collected prescriptions. From this individualized study it was found that the drug which was interacting with maximum of other drugs was found to be amlodipine (Enalapril, Flucanazole, Aspirin, Atenolol, Calcium Carbonate, Nebivolol, Furosemide, Indapamade, and Ramipril) and combination which is repeated mostly was amlodipine and atenolol.

From the above study, it may be concluded that the drug interaction cases constitutes $20 \%$ among the 151 hypertensive prescriptions. In future these drug interactions can be effectively overcome by dose adjustments, regular monitoring of blood pressure, renal function, elecrolytes, cautious use of combination of drugs, clinical monitoring of the patient, and laboratory observation of the patient especially in the cases of major and moderate drug interactions.

TABLE-1: NO. OF CASES COLLECTED IN EACH MONTH AND ITS PERCENTAGE IN EACH MONTH

\begin{tabular}{|l|l|c|c|}
\hline \multicolumn{1}{|c|}{ S.no } & \multicolumn{1}{|c|}{ Month } & $\begin{array}{c}\text { No.of } \\
\text { Cases }\end{array}$ & $\begin{array}{c}\% \text { of } \\
\text { Cases }\end{array}$ \\
\hline 1. & September 2015 & 18 & $12 \%$ \\
\hline 2. & October 2015 & 31 & $21 \%$ \\
\hline 3. & November 2015 & 33 & $22 \%$ \\
\hline 4. & December 2015 & 9 & $06 \%$ \\
\hline 5. & January 2016 & 6 & $04 \%$ \\
\hline 6. & February 2016 & 14 & $09 \%$ \\
\hline 7. & March 2016 & 23 & $15 \%$ \\
\hline 8. & April 2016 & 12 & $08 \%$ \\
\hline 9. & May 2016 & 5 & $03 \%$ \\
\hline
\end{tabular}

TABLE-2: DRUG DRUG INTERACTIONS SEVERITY AND, ITS REMEDY

\begin{tabular}{|c|c|c|c|c|c|}
\hline S.no & Drug1 & Drug2 & Severity & Effect & Remedy \\
\hline 1. & Amlodipine & Enalapril & Minor & $\begin{array}{l}\text { May have additive hypotensive } \\
\text { effects }{ }^{6} \text {. Therapeutic duplication } \\
\text { warnings. }\end{array}$ & $\begin{array}{l}\text { Carefull monitoring with systemic } \\
\text { blood pressure }\end{array}$ \\
\hline 2. & Amlodipine & $\begin{array}{l}\text { Flucanozol } \\
\text { es }\end{array}$ & Moderate & Synergistic Effect $^{7}$ & Caution \\
\hline 3. & Amlodipine & $\begin{array}{l}\text { Asprin low } \\
\text { strength }\end{array}$ & Moderate & $\begin{array}{l}\text { Moderate: May increase blood } \\
\text { pressure }\end{array}$ & $\begin{array}{l}\text { Need dose adjustment or BP is often } \\
\text { checked }\end{array}$ \\
\hline 4. & Amlodipine & Atenolol & Moderate & $\begin{array}{l}\text { It may have the additive effects in } \\
\text { lowering blood pressure and hart rate, } \\
\text { cardiac contractility, hypotension, } \\
\text { headache, dizziness, lightheadedness, } \\
\text { fainting and or changes in pulse or heart } \\
\text { rate9. Therapeutic duplication warnings }\end{array}$ & $\begin{array}{l}\text { Need a dose adjustment and or more } \\
\text { frequent monitoring }\end{array}$ \\
\hline 5. & Amlodipine & Nebivolol & Moderate & $\begin{array}{l}\text { Increase antiypertenve channel } \\
\text { blocking, Reduction in heart rate, } \\
\text { cardiac onuction, hypotension }{ }^{\mathbf{1 0}} \text {. }\end{array}$ & $\begin{array}{l}\text { Need a dose adjustments or more } \\
\text { frequent monitoring }\end{array}$ \\
\hline 6. & Amlodipine & $\mathrm{CaCO}_{3}$ & Moderate & $\begin{array}{l}\text { Calcium carbonate can decrease the } \\
\text { effect of amlodipine causes } \\
\text { hypotension }{ }^{\mathbf{1 1}} \text {. }\end{array}$ & $\begin{array}{l}\text { Need a dose adjustment of CCB and } \\
\text { more often BP checked }\end{array}$ \\
\hline 7. & Amlodipine & Ramipril & Minor & May have additive hypotensive effect. & $\begin{array}{l}\text { Need a carefull monitoring of } \\
\text { systemic BP }\end{array}$ \\
\hline 9. & Atenolol & Diazepam & Moderate & Hypotensive effect and Orthostasis ${ }^{13}$. & $\begin{array}{l}\text { Caution during coadministration. } \\
\text { Patient advised to avoid rising } \\
\text { abruptly from sitting or recumbent } \\
\text { position and to notify when they } \\
\text { experience dizziness, tachycardia, } \\
\text { lightheadedness, orthostasis. }\end{array}$ \\
\hline
\end{tabular}




\begin{tabular}{|c|c|c|c|c|c|}
\hline 10. & Atenolol & Asprin & Minor & $\begin{array}{l}\text { High doses of Salicylates may blunt the } \\
\text { effect of beta blockers }{ }^{\mathbf{2}} \text {. }\end{array}$ & $\begin{array}{l}\text { Dosage should modify and regular } \\
\text { monitoring is needed. }\end{array}$ \\
\hline 11. & Atenolol & $\begin{array}{l}\text { Theophylli } \\
\text { ne }\end{array}$ & Major & $\begin{array}{l}\text { May cause severe or fatal } \\
\text { bronchospasm by opposing theopylline } \\
\text { inducing bronchodilation, atenolol } \\
\text { reduces the CYP } 450 \text { hepatic } \\
\text { metabolism of theophylline }{ }^{\mathbf{1 5}} \text {. }\end{array}$ & $\begin{array}{l}\text { Beta blockers should avoided and } \\
\text { extreme caution if no alternatives are } \\
\text { available }\end{array}$ \\
\hline 12. & Atenolol & $\begin{array}{l}\text { Nicotinami } \\
\text { de }\end{array}$ & Moderate & $\begin{array}{l}\text { Multivitamin decreases the effects of } \\
\text { atenolol }{ }^{\mathbf{1 4}} \text {. }\end{array}$ & $\begin{array}{l}\text { Separate the administration times by } \\
\text { atleast } 2 \text { hours }\end{array}$ \\
\hline 13. & Metoprolol & Asprin & Minor & $\begin{array}{l}\text { Metoprolol may increase the aspirin } \\
\text { absorption and plasma concentrations } \\
\text { of salicylates, its clinical significance of } \\
\text { this effect is unknown }{ }^{\mathbf{1 5}} \text {. }\end{array}$ & Discontinued or dosage is modified \\
\hline 14. & Enalapril & Furosemide & Moderate & $\begin{array}{l}\text { Coadministration makes hypotension } \\
\text { and hypovolemia }{ }^{\mathbf{1 6}} \text {. }\end{array}$ & $\begin{array}{l}\text { Need a monitoring of } \mathrm{BP} \text {, diueresis, } \\
\text { electrolytes and renal function }\end{array}$ \\
\hline 14. & Enalapril & $\begin{array}{l}\text { Biphasic } \\
\text { isophane }\end{array}$ & Moderate & Hypoglycaemic effect like tremor & $\begin{array}{l}\text { Need a monitoring of blood glucose } \\
\text { levels }\end{array}$ \\
\hline 15. & Enalapril & Allopurinol & Major & $\begin{array}{l}\text { Hypersensitive reaction, neutropenia, } \\
\text { agranulocytosisand serious infections. } \\
\text { Fever, myalgia, arthralgia, exfoliative } \\
\text { dermatitis and stevens- johnsons } \\
\text { syndrome has been reported }^{17} \text {. }\end{array}$ & $\begin{array}{l}\text { Caution is required during its } \\
\text { combination especially wit renal } \\
\text { impairment. Periodic monitoring of } \\
\text { WBC is recommended. Discontinue if } \\
\text { symptoms arises }\end{array}$ \\
\hline 16. & Enalapril & Levodopa & Major & $\begin{array}{l}\text { Postural hypotension effect, May also } \\
\text { experience headache, dizziness, } \\
\text { lightheadedness, fainting and changes } \\
\text { in heart or pulse rate }{ }^{\mathbf{1 8}} \text {. }\end{array}$ & $\begin{array}{l}\text { Dose adjustments and hemodynamic } \\
\text { monitoring during coadministration is } \\
\text { required }\end{array}$ \\
\hline 17. & Furosemide & $\begin{array}{l}\text { Ciprofloxac } \\
\text { in }\end{array}$ & Minor & $\begin{array}{l}\text { Decreased renal clearance, increased } \\
\text { AUC, Plasma Concentration has } \\
\text { increased }^{\mathbf{1 9}} \text {. }\end{array}$ & Monitoring of renal clearance \\
\hline 18. & Furosemide & Digoxin & Moderate & $\begin{array}{l}\text { Diuretic induced hypokalaemia and } \\
\text { hypomagnesemia. Diueretics may } \\
\text { predispose patients on digitalis to } \\
\text { arrythhmias }{ }^{\mathbf{2 0}} \text {. }\end{array}$ & $\begin{array}{l}\text { Digoxin, magnesium and potassium } \\
\text { levels need to be monitored, } \\
\text { hypokalemia and hypomagnesemia } \\
\text { treated properly. }\end{array}$ \\
\hline 19. & Furosemide & $\begin{array}{l}\text { Indapamad } \\
\text { e }\end{array}$ & Moderate & $\begin{array}{l}\text { Both decrease the potassium, sodium, } \\
\text { magnesium and chloride levels in the } \\
\text { blood }^{\mathbf{2 1}} \text {. }\end{array}$ & $\begin{array}{l}\text { Caution is need during concomitant } \\
\text { use of loop diuretics }\end{array}$ \\
\hline 20. & Furosemide & Asprin & Minor & $\begin{array}{l}\text { Increase in sodium excretion, renal } \\
\text { failure, decreases the plasma renin } \\
\text { activity }{ }^{22} \text {. }\end{array}$ & Caution is need during loop diuretics \\
\hline 21. & Furosemide & Ramipril & Moderate & $\begin{array}{l}\text { Hypotension and hypovolemia, } \\
\text { Ramipril makes increase in urinary } \\
\text { excretion of sodium caused by loop } \\
\text { diuretics }^{\mathbf{2 3}} \text {. }\end{array}$ & $\begin{array}{l}\text { Monitoring of blood pressure, } \\
\text { diuresis, electrolytes, and renal } \\
\text { function is needed. Minimising the } \\
\text { dose of ACE inhibitors or removal of } \\
\text { diuretics }\end{array}$ \\
\hline 23. & Ramipril & $\begin{array}{l}\text { Spironolact } \\
\text { one }\end{array}$ & Major & $\begin{array}{l}\text { Hypotensive effect, extreme risk of } \\
\text { severe hyperkalsemia }^{24} \text {. }\end{array}$ & $\begin{array}{l}\text { Caution is needed especially in } \\
\text { patients with renal impairment, } \\
\text { diabetes, old age. Monitor serum } \\
\text { potassium and renal function. Avoid } \\
\text { potassium supplements. }\end{array}$ \\
\hline 24. & Digoxin & $\begin{array}{l}\text { Atorvastati } \\
\mathrm{n}\end{array}$ & Moderate & $\begin{array}{l}\text { Atorvastatin has been shown to increase } \\
\text { the plasma digoxin concentration }{ }^{25} \text {. }\end{array}$ & Monitoring of serum digoxin levels \\
\hline 25. & Nifedipine & Phenytoin & Moderate & $\begin{array}{l}\text { Phenytoin may decrease CCB serum } \\
\text { levels }{ }^{\mathbf{2 6}} \text {. }\end{array}$ & $\begin{array}{l}\text { Close clinical and laboratory } \\
\text { observation for evidence is } \\
\text { recommended. }\end{array}$ \\
\hline 26. & Nifedipine & $\mathrm{CaCo}_{3}$ & Moderate & Decreases the effect of CCBs & $\begin{array}{l}\text { Monitoring the effectiveness of CCB } \\
\text { therapy during coadministration wit } \\
\text { calcium products. }\end{array}$ \\
\hline
\end{tabular}

TABLE-3: NO.OF DRUGS INTERACTING WITH EACH ANTIHYPERTENSIVE AGENTS AND THEIR PERCENTAGE

\begin{tabular}{|c|l|l|l|c|c|}
\hline S.no & Drug & \multicolumn{1}{|c|}{ Class } & Interacting drugs & $\begin{array}{c}\text { No. of } \\
\text { drugs }\end{array}$ & $\begin{array}{c}\text { Percentage of each } \\
\text { drug interactions }\end{array}$ \\
\hline 1. & Amlodipine & $\begin{array}{l}\text { Calcium channel } \\
\text { blocker }\end{array}$ & $\begin{array}{l}\text { Enalapril, Flucanozole, Asprin, } \\
\text { Atenolol, Nebivolol, Indapamde, } \\
\text { Ramipril, CaCo }\end{array}$ & 8 & $24 \%$ \\
\hline 2. & Furosemide & Loop diuretics & $\begin{array}{l}\text { Enalapril, Aspirin, Ramipril, } \\
\text { Ciprofloxacin, Digoxin }\end{array}$ & 5 & $22 \%$ \\
\hline 3. & Atenolol & $\begin{array}{l}\text { Beta-adrenergic } \\
\text { blocker }\end{array}$ & $\begin{array}{l}\text { Aspirin, Nicotinamide, CaCo }, \\
\text { Etophylline, Amlodipine, Diazepam }\end{array}$ & 6 & $16 \%$ \\
\hline 4. & Enalapril & ACE Inhibitor & $\begin{array}{l}\text { Furosemide, Levodopa, Amlodipine, } \\
\text { Allopurinol, Insulin }\end{array}$ & 5 & $14 \%$ \\
\hline 5. & Ramipril & ACE Inhibitor & Amlodipine, Spiranolactone, & 3 & $8 \%$ \\
\hline
\end{tabular}


Evaluations of Drug-Drug Interactions in Hypertensive Patients in Secondary Care Hospital

\begin{tabular}{|c|l|l|l|c|c|}
\hline & & & Furosemide & 2 & $6 \%$ \\
\hline 6. & Digoxin & $\begin{array}{l}\text { Cardiac } \\
\text { glycoside }\end{array}$ & Atorvastatin, Furosemide & 2 & $5 \%$ \\
\hline 7. & Nifedipne & $\begin{array}{l}\text { Calcium channel } \\
\text { blocker }\end{array}$ & Phenytoin, $\mathrm{CaCo}_{3}$ & 2 & $5 \%$ \\
\hline 8. & Nebivolol & $\begin{array}{l}\text { Beta-adrenergic } \\
\text { blocker }\end{array}$ & Amlodipine, Aspirin & 2 \\
\hline
\end{tabular}

PROFORMA-1

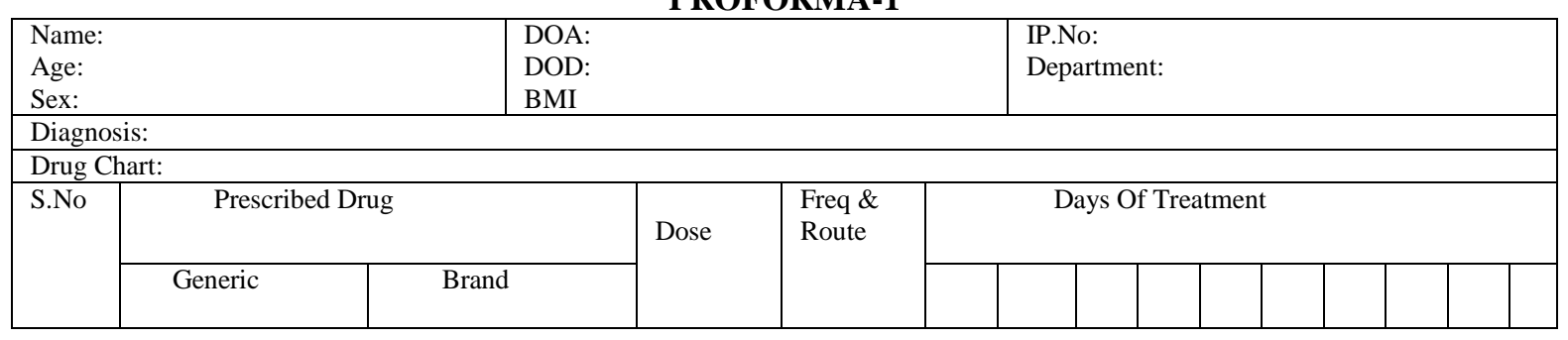

PROFORMA-2

\begin{tabular}{|c|c|c|c|c|}
\hline Name & Age & IP.No: & \multicolumn{2}{|c|}{ Diagnosis: } \\
\hline \multicolumn{5}{|l|}{ Drug Drug Interactions } \\
\hline Antihypertensive drug & Interacting drug & severity & Effect & Inference \\
\hline
\end{tabular}

\section{Acknowledgment}

I Dr. P.Sagar thankful to Care Hospital gave me an opportunity to analyse my research work.

\section{References:}

[1]. Stockley IH. Drug interactions. In: A source book of adverse interactions, their mechanisms, clinical importance and management. 5th ed. London: Pharmaceutical Press, 1999, 1-14.

[2]. Tipnis HP, Amrita B. Clinical Pharmacy. 1st ed. India: Career Publications, 2003

[3]. Daniel C Malone, Jacob Abarca, Philip D Hansten, Amy J Grizzle. Identification of Serious Drug-Drug Interactions: Results of the Partnership to Prevent Drug-Drug Interactions. Journal of the American Pharmaceutical Association, 44(2), 2004, 142-152.

[4]. K. Park, Prevention and Social medicine, case control study, page no-66.

[5]. www.sap.com

[6]. Kaplan NM. Amlodipine in the treatment of hypertension. Postgraduate Medical Journal, 67(15), 1991, 15-19.

[7]. Shjuuan Sun. Synergistic effect of fluconazole and calcium channel blocker against resistant candida albicans. PLos One 11(3)

[8]. Deleeuw PW. Nonsteroidal anti-inflammatory drugs and hypertension: the risks in perspective. Drugs, 51, 1996, 179-187.

[9]. Drugs.com

[10]. Di Somma S, et al. Antihypertensive effects of verapamil, captopril and their combination at rest and during dynamic exercise. Arzeneimittelforscung, 42, 1992, 103.

[11]. Oszko MA, Klutman NE. Use of calcium salts during cardiopulmonary resuscitation for reversing verapamil-associated hypertension. Clinical Pharmacolgy, 6, 1987, 448-449.

[12]. Spahn H, Languth P, Kirch W. Pharmacokinetics of salicylates administered with metoprolol. Arzeimittelforschung, 36,1986, 16971699.

[13]. Rodriguez de la Torre B, Dreher J, Malevany 1. Serum levels and cardiovascular effects of tricyclic antidepressants and selective serotonin reuptake inhibitors in depressed patients. Therapeutic Drug Monitoring, 23, 2001, 435-440.

[14]. Kirch W, Schafer-Korting M, Axthelm T, Kohler H, Mutschler E. Interaction of atenolol with furosemide and calcium and aluminium salts. Clinical Pharmacolology and Therapeutics, 30, 1981, 429-435.

[15]. Conrad KA, Nyman DW. Effects of metoprolol and propranolol on theophylline elim ination. Clinical Pharmacology, 27, 1987, 523-529.

[16]. Murphy BF, Whitworth JA, Kincaid-Smith P. Renal insufficiency with combinations of angiotensinconverting enzyme inhibitors and diuretics. British Medical Journal, 288, 1994, 844-845.

[17]. Pennel DJ, Nunan TO, O’Doherty MJ, Croft DN. Fatal Stevens-Johnson syndrome in apatient on captopril and allopurinol. Lancet, $1,1984,463$.

[18]. Product information. Stalevo 150(carbidopa/entacapone/levodopa). Novartis Pharmaceuticals, East Hanover, Nj.

[19]. Sudoh T, Fujimura A, Shiga T, Sasaki M, Harada K, Tateishi T, Ohashi, Ebihara A. Renal clearance of lomefloxacin is decreased by furosemide. European Journal of Clinical Pharmacology 46, 1994, 267-269.

[20]. Semple P, Tilstone WJ, Lawson DH. Furosemide and urinary digoxin clearance. N England Journal of Medicine, 293, 1975, 612613.

[21]. Leary WP, Reyes AJ. Drug interactions with diuretics. South African Medical Journal, 65, 1984, 455-461.

[22]. Valette H, Apoil E. Interaction between salicylate and two loop diuretics. British Journal of Clinical Pharmacology, 8, $1979,592-$ 594.

[23]. Good CB, McDermott L. Diet and serum potassium in patients on ACE inhibitors. JAMA, 274, 1995, 538.

[24]. Walmsley RN, White GH, Cain M, McCarthy PJ, Booth J. Hyperkalemia in the elderly. Clinical Chemistry, 30, 1984, 1409-1412.

[25]. Boyd RA, Stern RH, Stewart BH. Atorvastatin coadministration may increase digoxin concentrations by inhibition of intestinal Pglycoprotien-mediated secretion. Journal of Clinical Pharmacology, 40, 2000, 91-98.

[26]. Bahls FH, Ozuna J, Ritchie DE. Interactions between calcium channel blockers and the anticonvulsants carbamazepine and phenytoin. Neurology, 41, 1991, 740-742. 